\title{
Analisis Kesalahan Morfosemantik Pada Teks Terjemahan Siswa Madrasah Aliyah Darussalam Bogor
}

\author{
Deni Maulana ${ }^{\mathrm{a}, \mathbf{1}}$, Anwar Sanusia ${ }^{\mathrm{a}, 2}$
}

${ }^{a}$ Universitas Pendidikan Indonesia, Bandung, Indonesia

${ }^{1}$ denimaulana93@upi.edu; ${ }^{2}$ anwarsanusi@upi.edu

\begin{tabular}{|c|c|}
\hline Article info & A B S T R A C T \\
\hline Article history: & This study aims to uncover morphosemantic errors in \\
\hline $\begin{array}{l}\text { Received: } 13-01-2019 \\
\text { Revised : 10-05-2019 }\end{array}$ & Indonesian-Arabic language text translations conducted by \\
\hline Accepted: $23-03-2020$ & Bogor Darussalam Madrasah Aliyah (MA) students. This \\
\hline & research uses descriptive qualitative method with a content \\
\hline & $\begin{array}{l}\text { analysis model. The data source in this study is the result of } \\
\text { text translation from Indonesian to Arabic. Research shows }\end{array}$ \\
\hline & that there are student errors in translating texts using past \\
\hline & verbs (fi'il mādi) 14 (11\%), while non-pastoral verbs (fi'il \\
\hline & $\begin{array}{l}\text { mudāari ') amounted to } 111 \text { (89\%). Likewise, students are } \\
\text { weak in choosing the appropriate meaning when translating } \\
\text { from Indonesian to Arabic. }\end{array}$ \\
\hline
\end{tabular}

Keywords:

errors

morphosemantic

students

text translation

Penelitian ini bertujuan untuk mengungkap kesalahan morfosemantik pada teks terjemahan bahasa Indonesiabahasa Arab yang dilakukan oleh siswa Madrasah Aliyah (MA) Darussalam Bogor. Penelitian ini menggunakan metode deskriptif kualitatif dengan model analisis isi (content analysis). Sumber data dalam penelitian ini adalah hasil teks terjemahan dari bahasa Indonesia ke bahasa Arab. Penelitian menunjukkan bahwa terdapat kesalahan siswa dalam menerjemahkan teks menggunakan verba lampau ( $f i$ ' $i l$ $m \bar{a}$ di) $14(11 \%)$, sedangkan kesalahan verba nonlampau (fi'il mud̄āri') yang berjumlah 111 (89\%). Begitu juga siswa lemah dalam memilih makna yang sesuai ketika menerjemahkan dari bahasa Indonesa ke bahasa Arab.

Copyright $\odot 2020$ Institut Agama Islam Negeri Syekh Nurjati Cirebon. All rights reserved.

\section{PENDAHULUAN}

Menurut Syuhada (2011), morfologi adalah ilmu yang mempelajari bentuk dan pembentukan kata. Dalam linguistik Arab disebut dengan i'lm as-Sharf. I'lm as-Sharf adalah ilmu yang membahas dasar-dasar pembentukan kata dan konstruksi kata, termasuk di dalamnya imbuhan atau afiksasi (Asy'ari, 2016; Natsir, 2017). Bungatang (2017) menandaskan bahwa afiksasi adalah proses penambahan awalan atau prefiks, akhiran atau sufiks, sisipan atau infiks, dan gabungan antara awalan dan akhiran atau konfiks pada kata dasar. Selain mempelajari seluk-beluk bentuk kata serta pengaruh perubahan-perubahan bentuk kata terhadap golongan dan arti kata, morfologi juga mempelajari susunan bagianbagian kata-kata secara gramatikal (Fathoni, 2013). Morfologi juga mempelajari seluk-beluk bentuk kata serta fungsi perubahan-perubahan bentuk kata itu, baik fungsi gramatik maupun fungsi semantik (Nur, 2018).

Selaras dengan hal tersebut, semantik juga merupakan kajian makna, tanda, dan representasi, baik secara mental maupun linguistik (Tiawaldi \& Wahab, 2017). Pendek kata, ilmu semantik adalah ilmu yang mempelajari sistem tanda 
dalam bahasa yang dikenal dengan istilah ilmu al-Dalâlah. Hidayat (2012) menambahkan bahwa ilmu al-Dalâlah berkaitan dengan morfologi dan sintaksis. Jadi, morfosemantik merupakan gabungan dari subdisiplin ilmu linguistik, yaitu morfologi dan semantik dengan menggunakan morfologi sebagai dasar pijakan pengambilan makna semantiknya dan proses morfologisnya secara inflektif maupun derivatif (Luthfi, 2010). Lebih lanjut, analisis morfosemantik menurut El Qorny (2017) merupakan suatu penelitian bahasa dengan menggunakan teori morfologi dan teori semantik.

Dalam domain penerjemahan, aspek morfosemantik merupakan hal yang fundamental dalam membangun kata yang akurat. Hal ini biasanya dilihat dari perubahan kata dan makna yang dimaksud dalam bahasa sumber (Bsu) untuk dikomunikasikan ke dalam bahasa sasaran (Bsa). Dengan kata lain, makna terjemahan berarti Bsu yang diterjemahkan harus dikomunikasikan dengan benar dan harus memiliki tujuan makna yang sama dengan Bsu (Sanusi, 2019). Selain itu, penerjemah juga harus memperhatikan pemilihan kata, padanan kata yang tepat dan sepadan, supaya tidak melakukan kesalahan dalam proses penerjemahan (Fahmi, 2016). Oleh karena itu, penerjemah seyogianya memperhatikan aspek morfosintaksis guna menghasilkan terjemahan Bsa yang ekuivalen. Artinya, penerjemahan harus cermat dalam membangun kata dan menghindari kesalahan terjemahan yang berkaitan aspek morfosemantik.

Berkaitan dengan hal tersebut, Erlinda (2008) berpendapat bahwa kesalahan morfologis adalah ketidakmampuan penerjemah untuk menampilkan makna yang berasal dari imbuhan infleksional maupun derivasional pada satu kata. Wahab (2014) menambahkan bahwa kesalahan semantik adalah kesalahan keterikatan dalam memilih atau menggunakan kosakata yang sesuai pada struktur kalimat yang benar. Kesalahan morfosemantik pasti bertemali dengan analisis kesalahan berbahasa. Haniah (2018) mengungkap bahwa analisis kesalahan berbahasa dapat dipahami dari tiga kata yang digunakan. Analisis berarti proses membahas dan mengurai yang bertujuan ingin mengetahui sesuatu sehingga memungkinkan dapat mengetahui inti permasalahannya. Permasalahan yang ditemukan kemudian dikupas, dikritik, dan diulas lalu disimpulkan untuk dipahami.

Dalam analisis kesalahan, terdapat empat wilayah atau taksonomi kesalahan berbahasa, yaitu: taksonomi kesalahan linguistik; taksonomi kesalahan strategi performasi; taksonomi kesalahan komparatif; dan taksonomi kesalahan efek komunikasi. Taksonomi kesalahan linguistik mencakup (1) kesalahan tataran fonologi; (2) kesalahan tataran morfologi dan sintaksis; (3) kesalahan tataran semantik dan kata; dan (4) kesalahan tataran wacana (Suharto \& Fauzi, 2017). Menurut Supardi, dkk (2017), kesalahan berbahasa merupakan akibat penutur melanggar kaidah atau aturan tata bahasa gramatika. Senada dengan hal tersebut, Batmang (2013) berpendapat bahwa kesalahan berbahasa adalah anomali kaidah bahasa yang merupakan gejala alami dalam proses belajar bahasa kedua. Kesalahan yang terjadi pada pembelajar bahasa dapat dikatagorikan sebagai kesalahan interlingual dan kesalahan intralingual yang dapat berbentuk kesalahan penulisan ejaan, kesalahan sintaksis, kesalahan morfologis, kesalahan semantik, dan kesalahan menerjemahkan.

Ikhsanto \& Malik (2016) menjelaskan bahwa seorang penerjemah harus memiliki kemampuan yang diperlukan dalam menerjemahkan, yaitu kemampuan memecahkan masalah. Ihwal penerjemahan biasanya disebut penerjemahan. Pengetahuan seseorang akan makna kata atau kalimat akan sangat menentukan 
keberhasilan penerjemahan yang baik (Adriana, 2012). Menurut Darma (2007), penerjemahan merupakan padanan dari kata translation. Translation adalah nomina dari verbal to translate. Senada dengan Darma, Baihaki (2017) mengemukakan bahwa penerjemahan berarti memindahkan suatu bahasa sumber ke dalam Bsa. Istilah penerjemahan dalam bahasa Inggris memiliki beberapa makna, antara lain: merujuk pada bidang subjek umum, produk atau teks yang sudah diterjemahkan serta proses atau tindakan menghasilkan terjemahan, yang dikenal dengan penerjemahan.

Moeliono (dalam Syihabuddin, 2016) berpendapat bahwa penerjemahan itu merupakan kegiatan mereproduksi amanat atau pesan bahasa sumber dengan padanan yang paling dekat dan wajar di dalam bahasa penerima, baik dilihat dari segi arti maupun gaya. Idealnya, terjemah tidak akan dirasakan sebagai terjemahan. Namun, untuk mereproduksi amanat itu, mau tidak mau, diperlukan penyesuaian gramatis dan leksikal. Penyesuaian ini janganlah menimbulkan struktur yang tak lazim di dalam bahasa penerima. Pandangan Moeliono tersebut sejalan dengan Nida (dalam Syihabuddin, 2016) yang menilik penerjemahan sebagai reproduksi padanan pesan yang paling wajar dan alamiah dari Bsu ke dalam bahasa penerima dengan mementingkan aspek makna, kemudian gaya.

Walaupun gaya itu penting, makna mestilah menjadi prioritas utama dalam penerjemahan. Ekuivalensi ini selanjutnya diistilahkan dengan ekuivalensi dinamis, yaitu kualitas terjemahan yang mengandung amanat asli sumber yang telah dialihkan sedemikian rupa ke dalam Bsa sehingga tanggapan dari reseptor sama dengan tanggapan reseptor terhadap amanat asli sumber. Dengan kata lain, ekuivalensi dinamis menghasilkan tanggapan yang sama antara pembaca terjemahan dan pembaca asli sumber. Konsep utama penerjemahan adalah upaya mengalihkan teks Bsu dengan teks yang sepadan dalam Bsa. Dengan cara menemukan ekuivalensi yang memiliki struktur semantik yang sepadan (Al farisi, 2014). Menurut Newmark (1981), penerjemahan adalah suatu usaha untuk mengganti suatu pesan atau pernyataan tertulis dalam satu bahasa dengan pesan atau pernyataan yang sama dalam bahasa lain. Berdasarkan beberapa definisi tersebut dapat disimpulkan bahwa penerjemahan berfokus pada makna ekuivalen atau padanan suatu bahasa dalam bahasa lain.

Hal tersebut didukung oleh Geoffrey (2010) yang mengatakan bahwa bahasa mencerminkan budaya dan seorang penerjemahan harus mampu memahami budaya tersebut serta langkah stereotip dalam mereproduksi makna teks sumber. Artinya, penerjemahan tidak hanya terpaku dengan padanan leksikal pada kamus, tetapi juga mampu memaknainya dari sisi teks dan konteks. Sebab keberterimaan hasil penerjemahan akan dirasakan oleh pembaca. Al farisi (2018) menambahkan, teks terjemahan dengan tingkat kejelasan yang tinggi dapat membantu pembaca memahami teks lebih mudah. Dengan kata lain, pembaca hanya melihat 'hasil' dari praktik penerjemahan, bukanlah 'praktik' penerjemahannya (Machali, 2009).

Hasil penerjemahan yang baik seyogianya dibaca seolah-olah karangan asli yang ditulis dalam Bsa. Agar bisa menghasilkan terjemahan yang baik, seorang penerjemah hendaknya memperhatikan aspek-aspek linguistik dan nonlinguistik. Aspek lingustik, meliputi: aspek-aspek tataran morfologis (as-Sarf), sintaksis (alNaḥwu) dan semantik (al-Dalâlah) (Munip, 2005). Pada umumnya, ihwal penerjemahan merupakan salah satu kegiatan yang banyak dilakukan mahasiswa program studi bahasa asing di perguruan tinggi. Hal ini juga dilakukan oleh siswa 
Madrasah Aliyah pondok pesantren Dasrussalam Bogor yang pembelajarannya berorientasi pada kebahasaan. Kegiatan menerjemahkan ini tidak hanya dilakukan pada kegiatan pembelajaran di pesantren, tetapi juga pada mata pelajaran kepesantrenan di sekolah, seperti: mata pelajaran insya $\bar{a}^{\prime}$ atau mengarang dan muțāla' $a h$ atau membaca.

Namun pada kenyataanya, ihwal praktik penerjemahan yang dilakukan oleh siswa MA Darussalam Bogor masih banyak mengalami kendala. Kendala itu berupa hasil terjemahan yang mendekati pesan Bsu-nya, baik dari bahasa Indonesia ke dalam bahasa Arab maupun sebaliknya. Hal ini terjadi karena siswa masih melakukan kesalahan-kesalahan dalam penerjemahan. Dalam pembelajaran, hal ini disebut kesalahan berbahasa. Ada beberapa istilah yang digunakan para ahli untuk menunjukkan kesalahan dalam berbahasa, yaitu: error dan mistake. Menurut James (dalam Sari \& Dwi, 2016), kesalahan yang tergolong error tidak bisa diperbaiki sendiri karena pembelajar perlu diberikan pemahaman yang lebih relevan. Adapun kesalahan jenis mistake bisa diperbaiki sendiri oleh pembelajar apabila ditunjukkan kesalahan yang dilakukannya.

Berikut ini contoh penerjemahan bahasa Indonesia ke dalam bahasa Arab yang dilakukan oleh siswa MA Darussalam Bogor.

Teks Bahasa Indonesia:

"Kaum Muslimin memperingati Isra dan Mikraj Nabi Muhammad Saw. Pada bulan Rajab setiap tahunnya."

Hasil teks terjemahan ke dalam bahasa Arab:

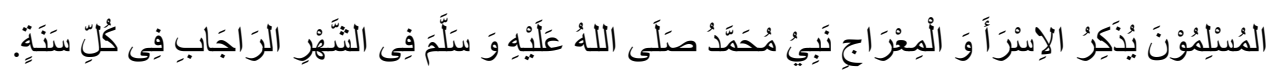

lalmuslimūna yużakiru 'l-isra' wa 'l-mi'rāji nabiyu Muhammad sallallahu 'alayhi wasallama fì 's-syahri 'l-rājābi fì kulli sanatin/

Jika dianalisis, hasil terjemahan tersebut terjadi kesalahan morfosemantik,

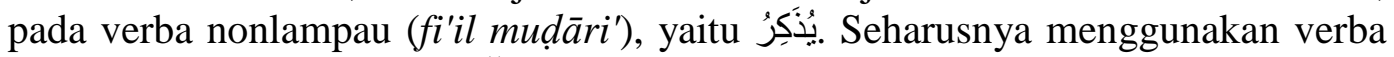
lampau (fi'il māạ), yaitu إِحْنَفَ Jadi, hasil terjemahan dalam bahasa Arab yang benar adalah:

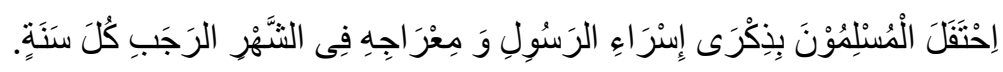

\section{/'ihtafala 'l-muslimūna biżikrā isrā' 'l-rasūli wa mi 'rājihi fì 's-syahri 'l- rajabi kulla sanatin/}

Pada dasarnya, penelitian tentang analisis kesalahan terjemahan teks ini sudah pernah dilakukan sebelumnya. Penelitian Fahmi (2016) menunjukkan bahwa kesalahan yang dilakukan oleh mahasiswa, meliputi: morfologi tataran kata, dan kata kerja serta kesalahan sintaksis tataran frasa, klausa, kalimat dan kesalahan huruf pada tataran preposisi. Kesalahan tersebut terjadi karena pengaruh bahasa Indonesia ke dalam bahasa Arab. Penelitian Alawiyah, Royani, \& Nawawi (2016) mengungkapkan bahwa dari 150 strategi yang terindentifikasi, ditemukan enam bentuk strategi penerjemahan yang muncul dari teks otentik hasil terjemahan mahasiswa dari bahasa Indonesia ke bahasa Arab. Enam bentuk itu, berupa: penambahan, penghilangan, transposisi, modulasi, peminjaman, dan kalke.

Erlinda (2008) dalam penelitiannya membahas kesalahan morfologis dan sintaksis dalam karya terjemahan. Penelitian tersebut jenis kesalahan morfologis, 
yaitu word formation. Kesalahan-kesalahan yang termasuk ke dalam kesalahan tersebut dapat dikelompokkan ke dalam dua kelompok, yaitu (1) sufiks infleksional pembentukan makna komparatif dan superlatif, serta (2) afiks derivasional pembentukan verba. Adapun kesalahan sintaksis tergambar dengan kesalahan urutan kata dan penyimpangan dalam pemakaian struktur frasa, klausa, dan kalimat. Kesalahan sintaksis dikelompokkan kepada tiga jenis, meliputi: (1) urutan kata, (2) penghilangan, dan (3) kegagalan mentransfer maksud teks Bsu. Berbagai penelitian tersebut masih terdapat hal rumpang yang belum diteliti, yaitu tentang analisis kesalahan morfosemantik pada teks terjemahan. Berdasarkan hal tersebut, penelitian ini akan berfokus pada analisis kesalahan morfosemantik teks terjemahan siswa MA Darussalam Bogor dalam bidang kajian verba bahasa Arab.

\section{METODE}

Penelitian ini menggunakan metode kualitatif dengan model analisis isi (content analysis). Menurut Mukhtar (2013), analisis isi merupakan suatu teknik penelitian untuk membuat inferensi-inferensi yang dapat ditiru (replicable). Kesahihah data dilakukan dengan memperhatikan konteks. Penelitian pendekatan dan metode ini dianggap relevan karena penelitian ini menitikberatkan pada penelitian dokumen. Adapun hal yang dimaksud adalah hasil karya terjemahan. Tujuan penelitian ini untuk mengungkapkan kesalahan morfosemantik pada teks terjemahan yang ditulis oleh siswa MA Darussalam Bogor. Partisipan dalam penelitian ini adalah 12 siswa kelas XII MA Darussalam. Kelas tersebut sudah mempelajari pelajaran nahwu dan șorof. Teknik pengambilan sampel menggunakan purposive sampling. Artinya, penentuan sampel didasarkan dengan pertimbangan dan kriteria tertentu sesuai tujuan penelitian (Lathifah, Syihabuddin, \& Al Farisi, 2017). Teks hasil terjemahan yang diperoleh dengan tes terjemahan dikumpulkan dan akhirnya terdapat 12 teks terjemahan. Berikut ini data yang berhasil diperoleh dari kelas XII MA Darussalam.

Tabel 1. Instrumen

\begin{tabular}{cl}
\hline No. & \multicolumn{1}{c}{ Terjemahan } \\
\hline 1. & Setiap orang seyogianya belajar dari orang lain \\
2. & Aku berharap Allah menerima taubatku. \\
3. & Pemimpin yang adil itu dicintai masyarakatnya. \\
4. & Umat Islam mendoakan warga Palestina \\
5. & Orang-orang beriman mencintai perbuatan-perbuatan mulia. \\
6. & Hal-hal yang cocok untuk individu, niscaya cocok pula untuk masyarakat. \\
7. & Manusia berupaya membangun peradaban yang agung. \\
8. & Kebutuhan manusia bukan hanya materi, namun juga spiritual. \\
9. & Kasih saying di antara umat manusia akan menghilangkan jurang pemisah dan \\
10. & permusuhan di antara mereka. \\
11. & Orandaraan mengarah kepada pembentukan persatuan umat Islam. \\
12. & Gerakan terjemah di kalangan umat Islam pernah mengantarkan mereka kepada \\
& masa keemasan yang mengagumkan. \\
\hline
\end{tabular}

Teks terjemahan tersebut, diambil dari teks buku berjudul Menjadi Penerjemah karya Ibnu Burdah Dosen Penerjemahan UIN Sunan Kalijaga Yogyakarta (Burdah, 2004). Instrumen yang digunakan dalam pengumpulan data 
adalah tes penerjemahan yang disesuaikan dengan tujuan penelitian. Siswa diminta untuk menerjemahkan teks dari bahasa Indonesia Bsu ke bahasa Arab Bsa dalam waktu yang sudah ditentukan. Teknik yang digunakan dalam menganalisis data adalah: (1) mengindentifikasi kesalahan-kesalahan morfosemantik pada hasil teks penerjemahan, (2) mengklasifikasi kesalahan morfosemantik dalam karya terjemahan, dan (3) memberikan koreksi terjemahan yang sesuai dan benar dari ahli.

\section{HASIL DAN PEMBAHASAN}

Kesalahan morfologis adalah ketidakmampuan penerjemah untuk menampilkan makna yang berasal dari imbuhan infleksional maupun derivasional pada satu kata. Kesalahan semantik adalah kesalahan keterikatan dalam memilih atau menggunakan kosakata yang sesuai pada struktur kalimat yang benar. Setelah dilakukan analisis ditemukanlah hasil penelitian sebagai berikut.

1. Jumlah kesalahan keseluruhan adalah 125, jumlah tersebut didapatkan dari hasil penelitian tes terjemahan terhadap 12 teks hasil terjemahan bahasa Indonesia ke dalam bahasa Arab siswa MA Darussalam Bogor, seperti tabel 2.

Tabel 2. Hasil Analisis Data

\begin{tabular}{|c|c|c|c|}
\hline & Fokus & Subfokus & Frekuensi \\
\hline \multirow[t]{3}{*}{$\begin{array}{l}\text { Kesalahan } \\
\text { penerjemahan }\end{array}$} & Morfosemantik & $\begin{array}{l}\text { Verba Lampau } \\
\text { (fi'il mādi) }\end{array}$ & 14 \\
\hline & & $\begin{array}{l}\text { Verba Nonlampau ( } f i \text { 'il } \\
\text { mud̄âri') }\end{array}$ & 111 \\
\hline & Jumlah & & 125 \\
\hline
\end{tabular}

2. Kesalahan morfosemantik yang ditemukan berjumlah 125 yang terbagi menjadi 2 kategori, yaitu kesalahan verba lampau (fi'il mädi) berjumlah $14(11 \%)$ dan kesalahan verba nonlampau (fi'il muḍāri') berjumlah 111 (89\%), seperti gambar 1.

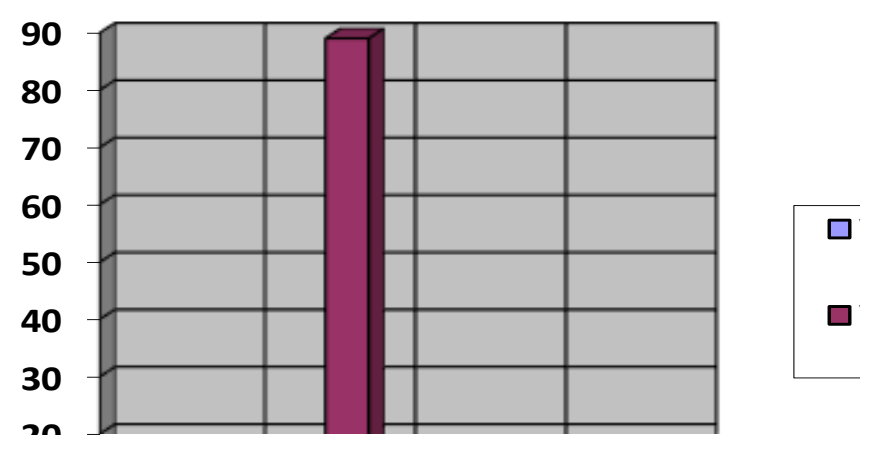

\section{Gambar 1. Kesalahan Morfosemantik}

Kesalahan yang diteliti difokuskan pada kesalahan morfosemantik. Berdasarkan analisis terhadap teks hasil terjemahan bahasa Indonesia ke dalam bahasa Arab, diperoleh data berupa 125 kesalahan yang sudah dikategorikan sebelumnya, berikut pembahasannya.

1. Verba Lampau (fi'il māại)

Teks sumber

: Orang-orang beriman mencintai perbuatanperbuatan mulia. 
Terjemahan teks salah : : الذين آمنو اير غب فى الأعال الثريفة

رغب المؤمنون فى الأعمال الفاضلة :

Kesalahan terjadi pada kata يرغب. Ini merupakan kekeliruan pada pemakaian kata verba nonlampau (fi'il mudāari'). Berdasarkan teks sumber, hal ini menunjukkan pekerjaan lampau maka seharusnya menggunakan verba lampau (fi'il māḍi). Kata يرغب merupakan bentuk verbal nonlampau (fi'il muḍāri') sedangkan رغب رغ رغ tersebut merupakan pembahasan morfologis.

2. Verba Nonlampau (fi'il mud̄āri')
a. Teks sumber
: Setiap orang seyogianya belajar dari orang lain.

Terjemahan teks salah : على على كل أناس يتعلم مع غيره :

Terjemahan teks benar : ينبغى لكل انسان أن يدرس من الآخرين :

Ketidaktelitian siswa dalam memilih kosakata bahasa Arab menyebabkan kesalahan pada kata عekeliruan ini pada pemakaian verba lampau (fi'il $m \bar{a}$ di). Tentu saja hal ini berimplikasi pada makna yang berbeda dan memiliki arti meronda. Padahal seharusnya menggunakan kata ينبنى yang artinya seyogianya. Seperti ini termasuk kesalahan semantik atau makna. Selain itu, kata ini menunjukkan pekerjaan nonlampau, maka seharusnya menggunakan verba nonlampau (fi'il muḍāri'). Perubahan makna tersebut merupakan pembahasan semantik.

b. Teks sumber : Aku berharap Allah menerima taubatku.

Terjemahan teks salah : الله يقبل توبتي :

أرجو أن ينوب الله علي : Terjemahan teks benar :

Kesalahan terjadi pada kata عسى berupa ketidakcermatan pada pemilihan bentuk verba lampau ( $f$ 'il mạdi). Hal ini juga berimplikasi pada makna yang berbeda dan memiliki arti semoga. Seharusnya kalimat ini menggunakan kata أرجو yang artinya berharap. Seperti ini termasuk kesalahan semantik atau makna. Selain itu, kata ini menunjukkan pekerjaan nonlampau, maka seharusnya menggunakan verba nonlampau (fi'il mudāari'). Perubahan makna tersebut merupakan pembahasan semantik.

c. Teks sumber : Pemimpin yang adil itu dicintai masyarakat.

رerjemahan teks salah : رغب في الناس راعية عادلون :

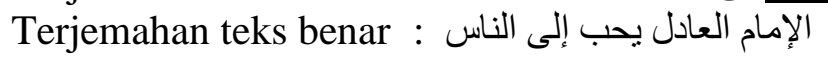

Kesalahan terjadi pada kata رغب النب dan merupakan kesalahan pada pemakaian verba lampau (fi'il mādi). Seharusnya kata yang digunakan يحب. Kata ini menunjukkan pekerjaan nonlampau, maka seharusnya menggunakan verba nonlampau (fi'il muḍāri'). Perubahan kata tersebut merupakan pembahasan morfologis.

d. Teks sumber : Hal-hal yang cocok untuk individu, niscaya cocok pula untuk masyarakat.

الأشياء المناسب لفرد تكن مناسبا فى المجتمج : Terjemahan teks salah

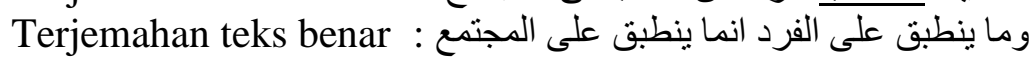

Kesalahan siswa dalam memilih kosakata bahasa Arab terjadi pada kata dan merupakan kesalahan pada pemakaian (isim fā'il). Seharusnya menggunakan kata ينطبق yang artinya cocok. Selain itu, kata tersebut menunjukkan pekerjaan nonlampau, maka seharusnya menggunakan verba nonlampau (fi'il muḍāri'). Perubahan kata tersebut merupakan pembahasan morfologis. 
e. Teks sumber

: Manusia berupaya membangun peradaban yang agung.

جرب الإنسان ليبنى الحضارة العزيزة : Terjemahan teks salah

Terjemahan teks benar : الناس يعملون على بناء الحاضرة لينارة العاليزة :

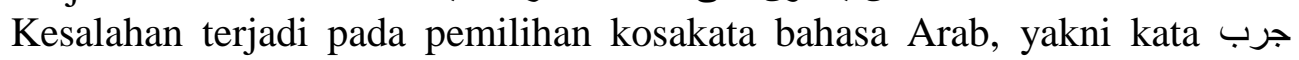
Begitu pun, verba yang digunakan menunjukkan verba lampau (fi'il mādi). Hal ini berimplikasi pada makna sehingga maknanya berbeda menjadi mencoba. Seharusnya kata yang digunakan يعملون dan berarti berupaya. Hal ini termasuk kesalahan semantik atau makna. Dari segi waktu, kata ini merujuk pekerjaan nonlampau, maka seharusnya menggunakan verba nonlampau (fi'il muḍ̄ari'). Perubahan makna tersebut merupakan pembahasan semantik.

f. Teks sumber : Kebutuhan manusia bukan hanya materi, namun juga spiritual.

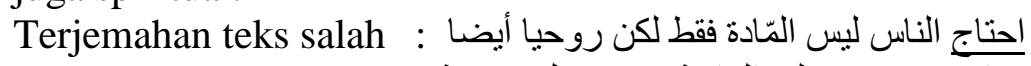

و ما يحتاج اليه الإنسان لا يقصر على المادية فحسب بل روحية : Terjemahan teks benar : لئل اليطان أيضا

Kesalahan terjadi pada kata احتاج berupa kekeliruan penggunaan verba lampau (fi'il madhi). Seharusnya kata yang diguna berupa يحتاج. Kata ini merujuk pekerjaan nonlampau, maka seharusnya menggunakan verba nonlampau (fi'il mudāari'). Perubahan kata tersebut merupakan pembahasan morfologis.

g. Teks sumber : Kasih sayang di antara umat manusia akan menghilangkan jurang pemisah dan permusuhan di antara mereka.

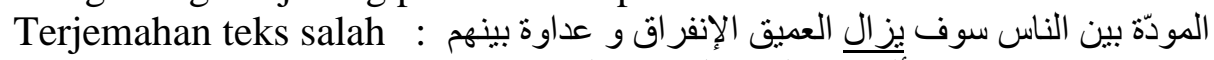

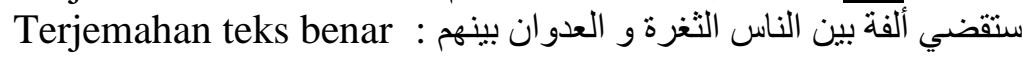

Ketidaktelitian siswa dalam memilih kosakata bahasa Arab menyebabkan kesalahan pada kata يز ال yang diartikan senantiasa. Kesalahan tersebut tentu saja berimplikasi pada makna. Seharusnya kata yang digunakan berupa yang berarti menghilangkan. Kesalahan ini termasuk pada bidang semantik atau makna.

h. Teks sumber : Persaudaraan mengarah kepada pembentukan persatuan umat Islam.

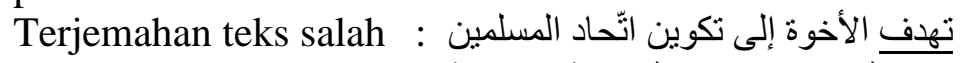

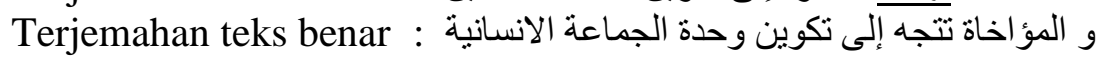

Ketidaktelitian siswa dalam memilih kosakata bahasa Arab menyebabkan kesalahan terjadi pada kata نهدف yang artinya bertujuan. Kesalahan tersebut berimplikasi pada makna. Seharusnya kata yang digunakan تتجه dan artinya mengarah. Kesalahan ini termasuk kesalahan semantik atau makna.

i. Teks sumber : Gerakan terjemah dikalangan umat Islam pernah mengantarkan mereka kepada masa keemasan yang mengagumkan.

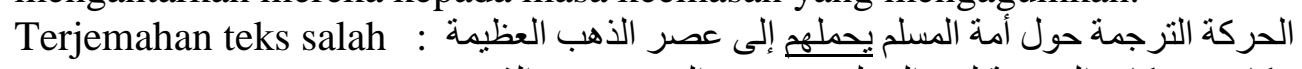
كانت حركات الترجمة لدى المسلمين تدفعهم إلى عصر هم الذهبى : Terjemahan teks benar : العجيب

Kekeliruan siswa dalam memilih kosakata bahasa Arab menyebabkan terjadi kesalahan pada kata بحمهر yang artinya membawa. Kesalahan tersebut berimplikasi pada makna. Seharusnya kata yang digunakan تدفعهم dan memiliki arti menghantarkan. Kesalahan ini termasuk kesalahan semantic atau makna. 


\section{SIMPULAN}

Berdasarkan analisis terhadap kesalahan morfosemantik terjemahan teks berbahasa Indonesia ke bahasa Arab yang dilakukan oleh siswa MA Darusssalam Bogor dapat disimpulkan bahwa siswa cendrung keliru dalam menerjemahkan teks menggunakan verbal lampau ( $f i$ 'il māḍi) atau verba nonlampau ( $f i^{\prime} i l$ muḍāri'). Siswa juga lemah dalam memilih makna yang sesuai. Kesalahan lain berupa generalisasi yang berasal dari transfer intralingual terhadap kaidah-kaidah dalam bahasa Arab sebagai bahasa target. Hal ini justru menyebabkan pembentukan kalimat lain yang relatif baru.

\section{DAFTAR PUSTAKA}

Al Farisi, M. Z. (2014). Pedoman Penerjemahan Arab Indonesia Strategi, Metode, Prosedur dan Teknik. Bandung: PT Remaja Rosdakarya.

Al Farisi, M. Z. (2018). The Impact of Techniques and Translation Ideology on the Clarity of Pragmatic Meanings Translation of the Qur'anic Imperative Verses. Indonesian Journal of Applied Linguistics, 7(3), 676 - 686.

Alawiyah, N. L., Royani, A., \& Nawawi, M. (2016). Terjemahan Teks Akademik Mahasiswa Program Studi Pendidikan Bahasa Arab. Arabiyat: Jurnal Pendidikan Bahasa Arab dan Kebahasaaraban, 3(2), 218 - 230.

Asy'ari, H. (2016). Keistimewaan Bahasa Arab Sebagai Bahasa Al-Qur'an. Jurnal Manajemen Pendidikan Islam (Nidhomul Haq), 1(1), 21 - 28.

Batmang. (2013). Kesalahan Fonologis dalam Berbicara Bahasa Arab pada Mahasiswa Matrikulasi STAIN Kendari. Jurnal Al-Izzah 8(1), 19 - 38.

Bungatang. (2017). Makna Aspektualitas Afiksasi dan Reduplikasi pada Verba Bahasa Bugis. Jurnal Retorika. 10(1), 8 - 12.

Burdah, I. (2004). Menjadi penerjemah Metode dan Wawasan Menerjemahkan Teks Arab. Yogyakarta: Tiara Wacana.

El Qorny, A. (2017). Produktivitas Fi'l dalam Perubahan dan Pemaknaan (Analisis Morfosemantik Terhadap Kamus Arab-Indonesia Karya Prof. Dr. H. Mahmud Yunus). Jurnal Lisan Arabiya, 2(1), 77 - 115.

Erlinda, R. (2008). Analisis Kesalahan Morfologis dan Sintaksis dalam Karya Terjemahan. Jurnal Penelitian Ilmu-ilmu Sosial, 6(1), 3 - 21.

Fahmi, A. K. (2016). Analisis Kesalahan Gramatikal Teks Terjemah (IndonesiaArab) dalam Pendidikan Bahasa Arab. Jurnal Kordinat, 17(1), 106 - 116.

Fathoni, H. (2013). Pembentukan Kata dalam Bahasa Arab (Sebuah Analisis Morfologis “K-T-B”). Jurnal At-Ta'dib, 8(1), 45 - 58.

Haniah. (2018). Analisis Kesalahan Berbahasa Arab pada Skripsi Mahasiswa Jurusan Bahasa dan Sastra Arab. Jurnal Arabi, 3(1), 23 - 34.

Hidayat, N. S. (2012). Problematika Pembelajaran Bahasa Arab. Jurnal Pemikiran Islam, 37(1), $82-87$.

Lathifah, F., Syihabuddin, \& Al Farisi, M.Z. (2017). Analisis Kesalahan Fonologi dalam Keterampilan Membaca Teks Bahasa Arab. Arabiyat: Jurnal Pendidikan Bahasa Arab dan Kebahasaaraban, 4(2), 174 - 184.

Luthfi, K. M. (2010) Mengugat Harakat Alquran. Yogyakarta: Madina Press.

Machali, R. (2009). Pedoman Bagi Penerjemah: Panduan Lengkap Bagi Anda yang Ingin Menjadi Penerjemah Profesional. Bandung: PT. Mizan Pustaka.

Mukhtar. (2013). Metode Praktis Penelitian Deskriptif Kualitatif. Ciputat: Referensi. 
Munip, A. (2005). Problematika Penerjemahan Bahasa Arab ke bahasa Indonesia; Suatu Pendekatan Error Analysis. Jurnal Al-Arabiyah, 1(2), 1 - 14.

Natsir, M. (2017). Pendekatan Analisis Morfologi dalam Pembelajaran Bahasa Arab. Jurnal Al-Bayan, 9(1), 40 - 86.

Newmark, P. (1981). Approaches to Translation (Language Teaching Methodology Series). Oxfort: Pergamon Press.

Nur, T. (2018) Morfologi Bahasa Arab Tinjauan Deskriftif. Bandung: Unpad Press.

Sanusi, A. (2019). The Quality Translation Analysis of Student Qirāah Text. Arabi: Journal of Arabic Studies, 4(1), 11 - 20.

Sari, P., \& Dwi, P. Y. (2016). Menemukan Kesalahan Gramatika dalam Esai Mahasiswa Bahasa Inggris dan Solusi Menghindarinya. Jurnal Bahasa Inggris Terapan, 2(2), $21-29$.

Suharto, T., \& Fauzi, A. (2017). Analisis Kesalahan Sintaksis dalam Buku Teks Bahasa Arab untuk Perguruan Tinggi Keagamaan Islam. Jurnal Arabi, 4(1), $20-37$.

Supardi, S., Hadi, S., Poedjosoedarmo, S., \& Suhandano, S. (2017). Tipe-Tipe kesalahan Konkordansi Gramatikal Sintaksis pada Frasa Bahasa Arab. Jurnal Bahasa dan Seni, 45(1), 1 - 12.

Syihabuddin. (2016). Penerjemahan Arab - Indonesia (Teori dan Praktek). Bandung: UPI Press.

Syuhada, A. (2011). Sistem Morfologi Nomina Variabel (Ism Mutasharrif) Bahasa Arab. Jurnal At-Ta'dib, 6(2), 269 - 289.

Tiawaldi, A., \& Wahab, M. A. (2017). Perkembangan Bahasa Arab Modern dalam Perspektif Sintaksis dan Semantik pada Majalah Aljazeera. Arabiyat: Jurnal Pendidikan Bahasa Arab dan Kebahasaaraban, 4(1), 1 - 19.

Wahab, M. A. (2014). Asasiayât fîtarâkib wal qawâid al-Arabiyyah wat tadrîbât al-Lughawiyyah. Jakarta: Markaz al-Lughah. 